\title{
Galectins: a key intersection between glycobiology and immunology
}

G.A. Rabinovich,

C.M. Riera, C.A. Landa and C.E. Sotomayor

\author{
Inmunología, Departamento de Bioquímica Clínica, \\ Facultad de Ciencias Q uímicas, \\ Universidad Nacional de Córdoba, Córdoba, Argentina
}

\begin{abstract}
\section{Correspondence}

G.A. Rabinovich

Inmunología

Departamento de Bioquímica Clínica

Facultad de Ciencias Químicas

Universidad Nacional de Córdoba

Ciudad Universitaria

Pabellón Argentina

CC61, Agencia Postal 4

5000 Córdoba

Argentina

Fax: +54-351-433-4174

E-mail: gabyrabi@onenet.com.ar

Presented at the XXVII Annual Meeting of the Brazilian Society of Biochemistry and Molecular

Galectins are a family of evolutionarily conserved animal lectins, widely distributed from lower invertebrates to mammals. They share sequence and structure similarities in the carbohydrate recognition domain and specificity for polylactosamine-enriched glycoconjugates. In the last few years significant experimental data have been accumulated concerning their participation in different biological processes requiring carbohydrate recognition such as cell adhesion, cell growth regulation, inflammation, immunomodulation, apoptosis and metastasis. In the present review we will discuss some exciting questions and advances in galectin research, highlighting the significance of these proteins in immunological processes and their implications in biomedical research, disease diagnosis and clinical intervention. Designing novel therapeutic strategies based on carbohydrate recognition will provide answers for the treatment of autoimmune disorders, inflammatory processes, allergic reactions and tumor spreading.
\end{abstract} Biology, Caxambu, MG, Brasil, May 23-26, 1998.

G.A. Rabinovich received the "Young Talent in Life-Sciences-98" award for this article from the Sociedade Brasileira de Bioquímica e Biologia Molecular and Amersham Pharmacia Biotech.

Research supported in part by CONICET, CONICOR, Fundación Antorchas and British Council.

Received December 2, 1998 Accepted February 1, 1999

\section{Introduction}

\section{What are galectins?}

Galectins are a family of evolutionarily conserved proteins widely distributed in nature from lower invertebrates to mammals (1-3). They are defined by their sequence and structure similarities in the carbohydrate recognition domain (CRD) and their specificity for polylactosamine-enriched glycoconjugates $(1,2)$. Ten mammalian galectins have been well identified in a wide variety of tissues of several species (4).

\section{How are galectins designed?}

According to their architecture, Hiraba- yashi and Kasai (5) classified this protein family into proto-type, chimera-type and tandem repeat type. Proto-type galectins include galectin-1 (6,7), -2 (8), -5 (9), -7 (10), human Charcot-Leyden crystal protein (11), frog galectins (12), electrolectin, which was the first galectin described (13), C. elegans 16$\mathrm{kDa}$ galectin (14), chicken isolectins C-14 and $\mathrm{C}-16(15,16)$, and sponge isolectins (17). They are non-covalent homodimers composed of two identical CRDs. On the other hand, chimera-type galectins exhibit a combined structure composed of a carboxy terminal CRD linked to a proline-, glycine-, and tyrosine-rich N-terminal domain. The only member of this family, galectin-3 (previously known as Mac-2, L-29, CBP-35 and $\operatorname{IgEBP})(18)$, has been mainly found in mam- 
mals, although it has also been detected in chickens (19). The third family of tandemrepeat galectins includes proteins with two distinct CRDs, such as galectins-4 (20), -6
(21), -8 (22) and -9 (23). The biochemical properties and tissue distribution of different galectins are summarized in Table 1 . Several galectin genes have been cloned and charac-

Table 1 - Galectin family: properties and tissue distribution.

MM, Molecular mass; AA residues, amino acid residues.

\begin{tabular}{|c|c|c|c|c|c|}
\hline $\begin{array}{l}\text { Designation } \\
\text { Structure }\end{array}$ & Species & $\begin{array}{l}\text { Tissue/cell } \\
\text { distribution }\end{array}$ & $\begin{array}{l}\text { Architectural } \\
\text { type }\end{array}$ & $\begin{array}{l}\text { MM } \\
\text { SDS/PAGE }\end{array}$ & AA residues \\
\hline Gal-1 & $\begin{array}{l}\text { human, rat, } \\
\text { mouse, pig, } \\
\text { hamster, } \\
\text { monkey, bovine, } \\
\text { ovine }\end{array}$ & $\begin{array}{l}\text { muscle, heart, lung, } \\
\text { placenta, brain, spleen, } \\
\text { liver, lymph nodes, } \\
\text { thymus, colon, prostate, } \\
\text { macrophage }\end{array}$ & proto & $14.5 \mathrm{kDa}$ & 134 \\
\hline Gal-2 & human, mouse & small intestine & proto & $14.5 \mathrm{kDa}$ & 132 \\
\hline Gal-3 & $\begin{array}{l}\text { human, rat, } \\
\text { mouse, dog, } \\
\text { hamster }\end{array}$ & $\begin{array}{l}\text { macrophage, colon, } \\
\text { leukemia cells, } \\
\text { 3T3 fibroblast }\end{array}$ & chimera & $29-35 \mathrm{kDa}$ & $>250$ \\
\hline Gal-4 & $\begin{array}{l}\text { human, rat, } \\
\text { mouse, pig }\end{array}$ & $\begin{array}{l}\text { alimentary tract, } \\
\text { epithelial cells }\end{array}$ & $\begin{array}{l}\text { tandem } \\
\text { repeat }\end{array}$ & $36 \mathrm{kDa}$ & 324 \\
\hline Gal-5 & rat & erythrocytes & proto & $17-18 \mathrm{kDa}$ & 144 \\
\hline Gal-6 & mouse & gastro-intestine & $\begin{array}{l}\text { tandem } \\
\text { repeat }\end{array}$ & $34 \mathrm{kDa}$ & 301 \\
\hline Gal-7 & human, rat & skin & proto & $14.5 \mathrm{kDa}$ & 136 \\
\hline Gal-8 & human, rat & liver, lung, kidney & $\begin{array}{l}\text { tandem } \\
\text { repeat }\end{array}$ & $34 \mathrm{kDa}$ & 316 \\
\hline Gal-9 & $\begin{array}{l}\text { human, rat, } \\
\text { mouse }\end{array}$ & $\begin{array}{l}\text { kidney, thymus, } \\
\text { Hodgkin's } \\
\text { lymphoma }\end{array}$ & $\begin{array}{l}\text { tandem } \\
\text { repeat }\end{array}$ & $35 \mathrm{kDa}$ & 322 \\
\hline Gal-10 & human & $\begin{array}{l}\text { eosinophil, } \\
\text { basophil }\end{array}$ & proto & $17 \mathrm{kDa}$ & 142 \\
\hline
\end{tabular}


terized and found to be associated with multiple regulatory elements.

\section{How were galectins identified?}

Although the first galectins were identified by their binding to $\beta$-galactoside-sugars (5), the most recent galectins, such as galectins -5 and -8 , were detected by immunoscreening cDNA libraries $(9,22)$ or by crossreactivity with other galectins identified so far (24). In this context galectin-9 was found by screening tumor cDNA libraries with sera from tumor-bearing patients (23).

\section{Why are galectins found in the extracellular milieu if they are designed as intracellular proteins?}

From the viewpoint of protein structure, galectins have been designed to play key roles inside the cells with an acetylated Nterminus, lack of signal sequences and biosynthesis in free ribosomes. Although novel intracellular functions have been reported in the last few years, such as mRNA processing (25), most of the functions assigned to $\beta$ galactoside-binding proteins are confined to the cell surface or extracellular milieu (26), suggesting that galectins are externalized by a non-classical secretory mechanism (27).

The intracellular concentration of galectins under physiological conditions is as high as $0.01 \mathrm{mM}$ in mammalian cells, but it can reach levels of approximately $0.1 \mathrm{mM}$ in critical situations. Galectin expression was found to be modulated during embryogenesis (28), being a typical hallmark of specific developmental stages. Moreover, galectin expression and subcellular distribution were reported to be highly susceptible to modulation by diverse stimuli such as sodium butyrate (29), viral infections (30), tumor suppressor genes (31) or inflammatory agents (18). In the present paper we discuss in detail the regulated expression of RMGal, a rat macrophage galectin-1-like protein, isolated and characterized in our laboratory, which showed immunomodulatory properties (24, 32 ). Gillenwater and colleagues (29) demonstrated that sodium butyrate, a known differentiating agent, was able to modulate galectin-1 content in human head and neck squamous carcinoma cells by a combination of transcriptional regulation and inhibition of histone deacetylation.

\section{What are the mechanisms involved in galectin secretion?}

This question still remains to be ascertained. However, two hypotheses have been considered regarding the externalization of galectin-1. The first involves the utilization of specific transmembrane carriers, like those used to export some bacterial toxins (33). The second considers the possibility that, after synthesis, galectin-1 becomes concentrated in plasma membrane evaginations prior to secretion and further externalized to form galectin-enriched extracellular vesicles (27). A kind of infrequent mechanism of externalization is also used by many cytokines and growth factors (34). Nevertheless, it is clear that galectins can be specifically targeted and secreted to exert their functions by interacting with intracellular or extracellular glycoconjugates.

\section{Functions of galectins}

\section{What is the functional significance of this evolutionarily conserved family of animal lectins?}

Conservation of galectins throughout animal evolution and their widespread distribution strongly suggest they could be implicated in critical biological functions requiring carbohydrate recognition. However, null mutant mice for galectin- 1 and -3 genes presented no major phenotypic abnormalities $(35,36)$, suggesting that they are not so cru- 
cial for life. In this context, it may be proposed that other members of this family could potentially compensate for the absence of these proteins, as suggested for targeted disruption of other important genes (37).

Galectins have been involved in several in vitro physiopathological processes requiring carbohydrate recognition, such as cell adhesion (26), cell growth regulation (38), immunomodulation $(39,40)$, apoptosis $(32$, 41), inflammation (42), embryogenesis (28), reproduction $(43,44)$, tumor spreading (45) and pre-mRNA splicing (25). It should be emphasized that the vast majority of galectin functions have been assigned to galectins- 1 and -3 . Hence, functions corresponding to other members of this protein family remain to be elucidated in future work.

\section{What are the molecular mechanisms involved in galectin functions?}

Although galectins are supposed to exert their biological roles by crosslinking glycoconjugate ligands, the precise mechanisms of action of these proteins and their signal transduction pathways remain largely unknown.

\section{Galectins in cell adhesion}

\section{What experimental evidence suggests that galectins could be involved in cell adhesion?}

Polylactosamine residues in extracellular matrix (ECM) glycoproteins such as laminin (46) and fibronectin (47) have been proposed to be candidate ligands for galectin-1. In view of this specific recognition, galectins have been postulated as powerful modulators of cell-cell and cell-ECM interactions.

\section{In this context, are galectins pro-adhesive or anti-adhesive proteins?}

Controversial results have been reported as to whether galectin-1 exerts a positive or a negative effect on cell adhesion to ECM glycoconjugates, raising the possibility that this dimeric protein could promote cell attachment or detachment according to cell type or cell developmental stage (26). At first sight, galectin-1 promoted cell adhesion in various cell types, such as melanoma cell lines (48), F9 teratocarcinoma cells (46), olfactory neurons (49), rhabdomyosarcoma cells (47) and CHO fibroblasts (46), by bridging oligosaccharides between specific cell surface glycoconjugates and ECM components. On the other hand, the presence of galectin-1 inhibited myoblast interaction with laminin by sterically blocking the laminin receptor $\alpha_{7} \beta_{1}$ integrin from recognizing laminin, thus allowing myoblasts to fuse into myotubes (50).

Similarly, the effects of galectin- 3 on cell adhesion were antagonic, depending on the physiopathological environment. While galectin-3 promoted neutrophil adhesion to laminin (51) in the context of inflammation, it showed a dramatic inhibitory effect on melanoma cell adhesion to ECM in metastases (52). In this context, expression of galectins1 and -3 in tumor cells was found to be correlated with high metastatic potential and low survival (53).

\section{Galectins in cell growth regulation}

\section{What is the role of galectins in cell growth regulation and differentiation?}

Galectins have shown critical antagonic effects on cell growth. Sanford and Harris-Hooker (54) reported a mitogenic effect of galectin-1 on vascular cells during alveolarization of postnatal rat lung. On the other hand, Wells and Mallucci (38) demonstrated that galectin- 1 acted as a powerful inhibitory growth factor on murine embryonic fibroblasts by controlling the exit from the G0 and G2 stages of the cell cycle. 
How can it be explained that antagonic stimulatory and inhibitory properties could be present within the same molecule?

To answer this question, an interesting study reports a biphasic modulation of cell growth by recombinant galectin-1 (55). While this $ß$-galactoside-binding protein was found to be mitogenic at low physiological concentrations, the growth-inhibitory properties were apparent in a higher concentration range, when tested on human cells in vitro. Moreover, galectin-1 may trigger either proliferation or cell growth arrest depending on the presence of concomitant environmental signals, cell cycle stages, or the expression of its carbohydrate receptors on the cell surface (55). Other signaling molecules, such as TGF $\beta$ (56) and FasL (57), have been shown to trigger different effects depending on the type and functional state of the cells.

\section{Galectins in the immune system}

The ultimate goal of immunologists is to manipulate the immune response, so that deficient responses can be potentiated, while harmful responses are suppressed.

\section{Are galectins important in the context of innate immunity?}

The innate immune system is important because it provides the early phases of host defense to protect the organism. Galectins have been implicated in different functions of innate immunity such as the respiratory burst (58), chemotaxis of eosinophils (59) and neutrophil migration during inflammatory episodes (51).

\section{What was the first clue suggesting that galectins could play a role in the regulation of the adaptive immune response?}

That galectins could be implicated in the regulation of the immune response was first inferred from galectin-1 localization in immune privileged sites of the body, such as the placenta $(6,43,44)$ and the eye $(60)$. In immune privileged sites multiple factors interact to prevent immunopathogenic processes from disrupting the critical functions of these particularly vulnerable organs. It has been recently demonstrated that FasL expression in immune privileged sites may have a key role in preserving tolerance by selectively killing inflammatory $\mathrm{T}$ cells by apoptosis (61). Accordingly, galectin-1 could be proposed as an alternative regulatory signal to regulate immune privilege. Expression of this protein in the first term gestation placenta would prevent inflammatory $T$ cells from harming the fetus (43). Furthermore, galectin-1 expression in the eye would protect this sensory organ from the devastating effects of an inflammatory response $(61,62)$. In agreement, a protein related to the galectin family called GRIFIN (galectin-related interfiber protein) was recently identified in the lens and in simple cellular structures of the eye (60).

\section{Are galectins also localized within the immune system?}

Galectin-1 has been identified not only in peripheral lymphoid organs such as lymph nodes (63) and spleen (24), but also in the thymus (64). Baum et al. (64) found that human thymic epithelial cells synthesized galectin-1, which bound to oligosaccharide ligands on the surface of thymocytes. Recently, Blaser et al. (65) found that galectin1 gene expression was strongly up-regulated in effector $\mathrm{T}$ cells. In addition, this protein was able to inhibit antigen-induced proliferation of naive and memory CD8+ T cells, acting as an autocrine negative growth factor (65). When this inhibitory mechanism was studied in detail, it was clear that galectin-1 switched off $\mathrm{T}$ lymphocyte effector functions by arresting cell cycle progression at 
the level of the $S$ and $\mathrm{G}_{2} / \mathrm{M}$ stages (66).

\section{What is the association between galectins and atopic diseases?}

Recent studies have shown that galectin3 , formerly defined as an Ig E-binding protein, was able to inhibit IL-5 gene transcription and protein release from human eosinophils and allergen-specific T cell lines (67). The possibility to shut down the IL-5 pathway could be determinant in the regulation of the $\mathrm{T}$ helper 2-dependent allergic reactions. Further investigations will be needed to clarify the mechanisms involved in this process.

\section{What is the association between galectins and autoimmunity?}

Galectin-1 has shown immunosuppressive properties in two experimental models of autoimmunity. Administration of recombinant galectin-1 prevented clinical and histopathological manifestations of experimental autoimmune encephalomyelitis (EAE) in susceptible Lewis rats (39) and autoimmune myasthenia gravis (EAMG) in rabbits (40).

\section{What kind of molecular mechanisms are involved in these immunomodulatory properties?}

Although the precise mechanisms involved in these properties in vivo still remain to be elucidated, hypotheses have been raised concerning the ability of galectin- 1 to affect processes in $\mathrm{T}$ cell suppressor commitment and in sensitization or deletion of antigenspecific T cells $(39,40)$. Interestingly, in the last few years evidence has been obtained concerning the implications of galectin-1 in apoptosis of mature $T$ cells $(31,41,43)$ and particular subsets of immature cortical thymocytes (59), thus providing a breakthrough in glycoimmunology.

\section{What was the first clue indicating that galectins could be implicated in programmed cell death?}

The first clue was raised when Goldstone and Lavin (68) reported in 1991 that the galectin-1 gene was overexpressed during glucocorticoid-induced cell death.

\section{What is the role of galectin-1 in central tolerance?}

Concerning the immune system, cell death programs promote tolerance by deletion of autoreactive lymphocytes in the central lymphoid organs and termination of immune responses in the peripheral immune system. At the central level, lymphocytes are susceptible to positive (69) and negative (70) selection. Immature $T$ cells that recognize selfpeptides with high affinity in the context of autologous major histocompatibility complex (MHC) molecules undergo negative selection by programmed cell death (70). $\mathrm{T}$ lymphocytes that fail to receive antigen stimulation (neglected cells) also undergo a default apoptotic program (69). The remaining $\mathrm{T}$ cells, which bind to peptide MHC complexes with low affinity, are positively selected to survive. In the context of new molecules involved in the machinery of central death, galectin-1 expressed by human thymic epithelial cells (64) has been recently shown to induce apoptosis of cortical thymocytes (71). The model of galectin-1 gene knock-out mice (35) will be useful to elucidate the precise role of galectin-1 in the elimination of non-selected and negatively selected cells during thymocyte development.

\section{What is the role of galectin-1 in peripheral tolerance?}

Activation-induced cell death of mature peripheral $\mathrm{T}$ cells is indeed one of the mechanisms aimed at preventing the expansion of dominant autoaggressive clones (72). In this 
context, galectin-1 has also been reported to induce apoptosis of mature T cells $(32,41,43)$. The apoptotic effect of soluble galectin-1 depended upon the activation state of T cells. Perillo et al. (41) clearly showed that galectin-1 induced apoptosis of mature $\mathrm{T}$ cells bearing the CD45RO splicing product, which was found to be differentially glycosylated (73). This provides an alternative mechanism for explaining the immunosuppressive properties exhibited by this highly conserved protein family.

\section{What is the link between apoptosis and autoimmunity?}

The importance of decreased apoptosis in the etiology of autoimmune disorders has been highlighted by the occurrence of lupuslike disorders in MRL-lpr/lpr or $\mathrm{C} 3 \mathrm{H}-\mathrm{gld} /$ gld mouse strains, carrying spontaneous mutations in Fas or FasL genes (74), and in particular by the dominant Fas gene mutation associated with Canale-Smith syndrome, a human autoimmune lymphoproliferative disorder (75).

\section{Galectins-1 and -3: why a novel paradigm?}

Antagonic functions have been assigned to galectin-1 and galectin-3, providing clues for a novel paradigm. While galectin-1 has been shown to induce $\mathrm{T}$ cell apoptosis $(32,41,43)$, galectin-3 has been conversely shown to prevent cell death (76). Similarly to members of the Bcl-2 family, galectins-1 and -3 belong to an additional family of proteins with high sequence homologies but opposite effects on cell survival (Figure 1). As clearly shown in the Figure, $\mathrm{Bcl}-2$ and $B c l-X_{L}$ are negative regulators of apoptosis, whereas Bax, Bad, and Bak contribute to a positive signal in the regulation of cell death (77). Transfection of galectin-3 cDNA into leukemia $\mathrm{T}$ cells conferred resistance to apoptosis induced by Fas ligation and staurosporine (76). Of particular interest, galectin3 showed a significant sequence similarity to $\mathrm{Bcl}-2$, mainly concentrated in the functional BH1 (NWGR) domain. Although this paradigm between galectins- 1 and -3 seems to be attractive, it should not be conceived as a general principle. Future studies should challenge this paradigm in the context of other physiological systems. Consistently, expression of galectins- 1 and -3 was found to be differentially regulated during mammalian gestation $(43,44)$. Iglesias et al. (44) reported the coexistence of mitogenic galectin-3 and apoptotic galectin-1 (43) in ovine placenta. Interestingly, galectin-3 expression was found to be decreased in term ovine placenta, in comparison with the middle of the gestation period. In contrast, no significant decrease was observed in galectin-1 expression. In this context, one might speculate that differential expression of both B-galactoside-binding lectins in ovine placenta could be associated with selective requirements at different developmental stages of gestation.

Furthermore, the participation of other members of the galectin family in the control of programmed cell death should also be considered. In this sense, galectin-9, a novel

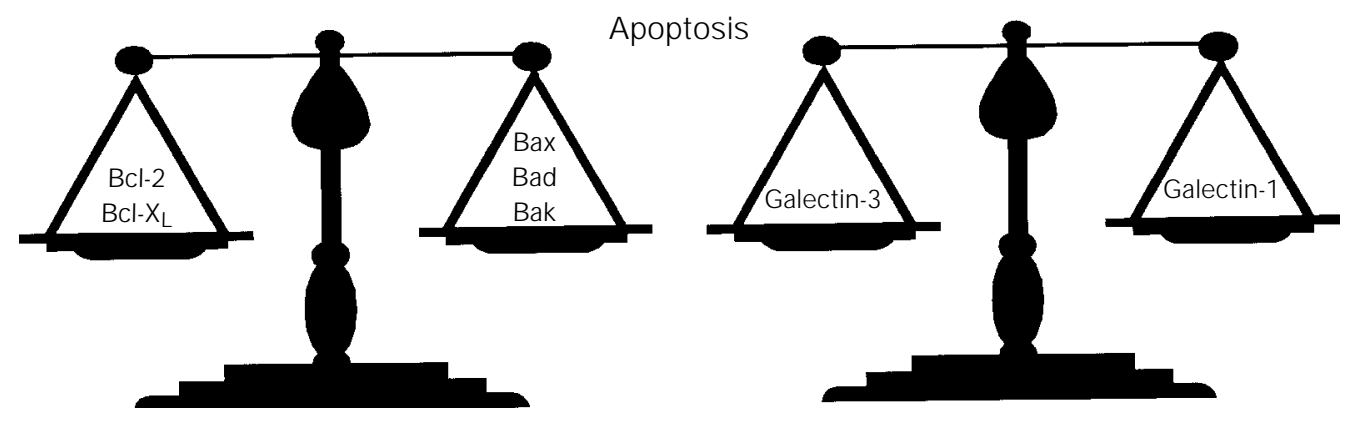

Figure 1 - Galectins-1 and -3: a novel paradigm in the regulation of programmed cell death. Galectins- 1 and -3 represent an additional family of proteins similar to the Bcl-2 family, where different members exhibit sequence and structure similarities, but opposite effects on cell survival. 
tandem repeat lectin, has recently shown strong apoptotic activity toward murine thymocytes (78).

\section{What is the functional significance of galectin-1 in activated macrophages?}

Macrophages (Møs) play important roles in a wide spectrum of events from innate immunity to adaptive immune response (24). Since galectin-1 had shown such immunomodulatory properties, we wondered whether it could be possible to identify its presence in key immunoregulatory cells such as M $\phi s$ and further demonstrate its functional meaning for target cells.

By means of immunochemical and immunocytochemical studies, we have identified the presence of a $15-\mathrm{kDa}$ soluble protein with key features of mammalian galectin-1 in rat peritoneal Møs by using a polyclonal $\mathrm{Ab}$ raised against the extensively studied C16 chicken isolectin (24). Rat macrophage galectin (RMGal) was purified from chemically activated macrophages by a single step affinity chromatography on a lactosylSepharose matrix, resulting in the isolation of a sharp protein band of $15 \mathrm{kDa}$, an isoelectric point of 4.8 and high hemagglutinating activity specifically inhibited by saccharides bearing a $B$-D-galactoside configuration (32). This protein behaved as a dimer under nondenaturing conditions, and internal amino acid sequencing revealed extensive homologies (80-90\%) with other members of the galectin-1 subfamily. Taken together, all the properties described resembled those exhibited by mammalian galectin-1 (32).

Resident, inflammatory or chemically activated Møs must be viewed as distinct cell subpopulations, since they show different phenotypes according to their activation status (24). In light of this observation, the next question we tackled was related to the regulation of total and surface RMGal expression in different Mø subpopulations. By Western blot analysis and further densitometric quantitation, we found a 5-fold increase in total galectin expression in chemically activated Møs and a 2-fold increase in inflammatory Møs in comparison to peritoneal resident cells (24). Moreover, modulation of RMGal expression was accompanied by an increase in cell surface immunostaining as shown by FACS analysis of non-permeabilized cells (24). Modulation of galectin expression and subcellular distribution strongly suggested that it could be implicated in crucial immunological processes mediated by Møs. By using current techniques to evaluate apoptosis, such as TUNEL assay, transmission electron microscopy and DNA fragmentation assay, we concluded that RMGal was clearly involved in apoptosis of mature T-cells and that this effect was dependent on its carbohydrate recognition domain. These results were more significant than those obtained using a heterologous system (79). Consistently, it has been reported that monocytes and dendritic cells from peripheral blood of healthy individuals can induce apoptosis of mitogen-activated T-cells (80).

\section{Concluding remarks and future perspectives}

Elucidation of the molecular mechanisms involved in galectin functions will provide new insights in biomedical research, disease diagnosis, prognosis and clinical therapy.

At the level of disease diagnosis, Lutomski et al. (81) reported the presence of autoantibodies against galectin-1 in sera of patients with neurological disorders, particularly multiple sclerosis. Moreover, aberrant expression of galectins on the surface of tumor cells seems to be indicative of a worse prognosis (53).

At the level of clinical therapy, future research should focus on the identification of new strategies for treatment of autoimmune diseases, inflammatory processes, allergic reactions and tumor spreading using galectins or galectin antagonists. First, the 
possibility to regulate the apoptotic threshold of autoreactive T cells using galectin-1 would be beneficial in autoimmunity. Second, down-regulation of the IL-5 gene by galectin-3 would be important in the treatment of allergic processes. Finally, neutralizing antibodies or antisense oligonucleotides aimed at inhibiting galectins- 1 and -3 expression would potentially decrease the metastatic potential of tumor cells

\section{Acknowledgments}

We would like to give special thanks to all the people who contributed to our work during the last few years, especially to Drs. Mercedes Iglesias, Nidia Modesti, Carlota Wolfenstein-Todel, Yuti Chernajovsky, Ofer Lider, Hanna Dreja, Gordon Daily, José Luis Bocco and Leonardo Castagna.

\section{References}

1. Barondes SH, Cooper DNW, Gitt MA \& Leffler H (1994). Galectins: structure and function of a large family of animal lectins. J ournal of Biological Chemistry, 269: 20807-20810.

2. Barondes SH, Castronovo V, Cooper DNW, Cummings RD, Drickamer K, Feizi T, Gitt MA, Hirabayashi J , Hughes C, Kasai K, Leffler H, Liu F, Lotan R, Mercurio AM, Monsigni M, Pillai S, Poirer F, Raz A, Rigby PWJ, Rini J M \& Wang JL (1994). Galectins: a family of animal galactosidebinding lectins. Cell, 76: 597-598.

3. Kasi K \& Hirabayashi J (1996). Galectins: a family of animal lectins that decipher glycocodes. J ournal of Biochemistry, 119: 1-8.

4. Leffler H (1997). Introduction to galectins. Trends in Glycoscience and Glycotechnology, 45: 9-19.

5. Hirabayashi J \& Kasai K (1993). The family of metazoan metal-independent ß-galactoside-binding lectins: structure, function and molecular evolution. Glycobiology, 3: 297-304.

6. Hirabayashi J \& Kasai K (1984). Human placenta ß-galactoside-binding lectin. Purification and some properties. Biochemical and Biophysical Research Communications, 122: 938-944.

7. Gitt MA \& Barondes SH (1991). Genomic sequence and organization of two members of a human lectin gene family. Biochemistry, 30: 82-89.

8. Gitt MA, Massa SM, Leffler H \& Barondes $\mathrm{SH}$ (1992). Isolation and expression of a gene encoding L-14-II, a new human soluble lactose-binding lectin. J ournal of Biological Chemistry, 267: 10601-10606.

9. Gitt MA, Wisers MF, Leffler $H$, Herrmann $\mathrm{J}$, Xia Y-R, Massa SM, Cooper DNW, Luis AJ \& Barondes SH (1995). Sequence and mapping of galectin-5, a ß-galactosidebinding lectin, found in rat erythrocytes. J ournal of Biological Chemistry, 270: 5032-5038.

10. Magnaldo $T$, Bernerd $F \&$ Darmon $M$ (1995). Galectin-7, a human 14-kDa S-lectin, specifically expressed in keratinocytes and sensitive to retinoic acid. Developmental Biology, 168: 259-271.

11. Ackerman SJ, Corrette SE, Rosenberg HF, Bennet J C, Mastrianni DM, NicholsonWeller A, Weller PF, Chin DT \& Tenen DG (1993). Molecular cloning and characterization of human eosinophil Charcot-Leyden cristal protein (lysophospholipase). J ournal of Immunology, 150: 456-468.

12. Vasta GR, Ahmed $H$, Amzel LM \& Bianchet MA (1997). Galectins from amphibian species: carbohydrate specificity, molecular structure and evolution. Trends in Glycoscience and Glycotechnology, 9: 131-144.

13. Paroutaud $\mathrm{P}$, Levi G, Teichberg $\mathrm{VI} \&$ Strosberg AD (1987). Extensive amino acid homologies between animal lectins. Proceedings of the National Academy of Sciences, USA, 84: 6345-6348.

14. Hirabayashi J, Ubukata T \& Kasai K (1996). Purification and molecular characterization of a novel 16-kDa galectin from the nematode Caenorhabditis elegans. J ournal of Biological Chemistry, 271: 2497-2505.

15. Ohyama Y, Hirabayashi J, Oda Y, Oono S, Kawasaki H, Suzuki K \& Kasai K (1986). Nucleotide sequence of chick $14 \mathrm{~K}$ ß-galactoside-binding lectin mRNA. Biochemical and Biophysical Research Communications, 134: 51-56.

16. Sakakura Y, Hirabayashi J, Oda Y, Ohyama Y \& Kasai K (1990). Structure of chicken 16-kDa ß-galactoside-binding lectin: complete amino acid sequence, cloning of
cDNA and production. J ournal of Biological Chemistry, 265: 21573-21579.

17. Pfeifer K, Haasemann M, Gamulin V Bretting $\mathrm{H}$, Fahrenholz $\mathrm{F} \&$ \& Muller WE (1993). S-type lectins occur also in invertebrates: high conservation of the carbohydrate recognition domain in the lectin genes from the marine sponge Geodia cydonium. Glycobiology, 3: 179-184.

18. Sato S \& Hughes RC (1994). Regulation of secretion and surface expression of Mac2 , a galactoside-binding protein of macrophages. J ournal of Biological Chemistry, 269: 4424-4430.

19. Nurminskaya M \& Linsenmayer TF (1996). Identification and characterization of upregulated genes during chondrocyte hypertrophy. Developmental Dynamics, 206: 260-271.

20. Oda Y, Herrmann J, Gitt MA, Turck CW, Burlingame AL, Barondes SH \& Leffler H (1993). Soluble lactose-binding lectin from rat intestine with two different carbohydrate-binding domains in the same chain. J ournal of Biological Chemistry, 268: 5929-5939.

21. Gitt MA, Colnot C, Poirier F, Nani KJ Barondes SH \& Leffler H (1998). Galectin4 and galectin- 6 are two closely related lectins expressed in mouse gastrointestinal tract. J ournal of Biological Chemistry, 273: 2954-2960.

22. Hadari $Y R$, Paz K, Dekel R, Mestrovic T, Accili D \& Zick Y (1995). Galectin-8: a new rat lectin related to galectin-4. J ournal of Biological Chemistry, 270: 3447-3453.

23. Wada J \& Kanwar YS (1997). Identification and characterization of galectin-9, a novel ß-galactoside-binding mammalian lectin. J ournal of Biological Chemistry, 272: 6078-6086.

24. Rabinovich GA, Castagna LF, Landa CA, 
Riera CM \& Sotomayor CE (1996). Regulated expression of a 16-kd galectin-like protein in activated rat macrophages. J ournal of Leukocyte Biology, 59: 363370.

25. Dagher SF, Wang JL \& Patterson RJ (1995). Identification of galectin-3 as a factor in pre-mRNA splicing. Proceedings of the National Academy of Sciences, USA, 92: 1213-1217.

26. Cooper DNW (1997). Galectin-1: secretion and modulation of cell interactions with laminin. Trends in Glycoscience and Glycotechnology, 9: 57-67.

27. Cooper DNW \& Barondes SH (1990). Evidence for export of a muscle lectin from cytosol to extracellular matrix and for novel secretory mechanism. J ournal of Cell Biology, 110: 1681-1691.

28. Poirier F, Timmons PM, Chan C-T, Guenet $J-L \&$ Rigby $P$ (1992). Expression of the L14 lectin during mouse embryogenesis suggests multiple roles during pre- and post-implantation development. Development, 115: 143-155.

29. Gillenwater A, Xu XC, Estrov Y, Sacks PG, Lotan D \& Lotan R (1998). Modulation of galectin-1 content in human head and neck squamous carcinoma cells by sodium butyrate. International J ournal of Cancer, 75: 217-224.

30. Hsu DK, Hammes SR, Kuwabara I, Greene WC \& Liu FT (1996) Human T lymphotropic virus-I infection of human $T$ lymphocytes induces expression of the beta-galactoside binding lectin, galectin-3. J ournal of Biological Chemistry, 148: 16611670.

31. Gaudin J C, Arar C, Monsigny M \& Legrand A (1997). Modulation of the expression of the rabbit galectin-3 gene by $\mathrm{p} 53$ and cHa-ras proteins and PMA. Glycobiology, 7: 1089-1098.

32. Rabinovich GA, Iglesias MM, Modesti NM, Castagna LF, Wolfenstein-Todel C, Riera CM \& Sotomayor CE (1998). Activated rat macrophages produce a galectin-1-like protein that induces apoptosis of $T$ cells: biochemical and functional characterization. J ournal of Immunology, 160: 4831-4840.

33. Cleves $\mathrm{AE}$, Cooper DN, Barondes $\mathrm{SH} \&$ Kelly RB (1996). A new pathway for protein export in Saccharomyces cerevisiae. J ournal of Cell Biology, 133: 1017-1026.

34. Rubartelli A, Bajetto A, Allavena G, Wollman E \& Sitia R (1992). Secretion of thioredoxin by normal and neoplastic cells through leaderless secretory pathway. J ournal of Biological Chemistry, 267: 24161-24164.
35. Poirrier F \& Robertson EJ (1993). Normal development of mice carrying a null mutation in the gene encoding the L-14 Stype lectin. Development, 119: 12291236.

36. Colnot C, Fowlis D, Ripoche MA, Bouchaert I \& Poirier F (1998). Embryonic implantation in galectin-1/galectin-3 double mutant mice. Developmental Dynamics, 211: 306-313.

37. Colnot $C$, Ripoche MA, Fowlis D, Cannon V, Scaerou F, Cooper DNW \& Poirier F (1997). The role of galectins in mouse development. Trends in Glycoscience and Glycotechnology, 9: 31-40.

38. Wells V \& Mallucci L (1991). Identification of an autocrine negative growth factor: mouse ß-galactoside-binding protein is a cytostatic factor and cell growth regulator. Cell, 64: 91-97.

39. Offner $\mathrm{H}$, Celnik B, Bringman $\mathrm{T}$, CasentiniBorocz D, Nedwin GE \& Vandebark A (1990). Recombinant human ß-galactoside-binding lectin suppresses clinical and histological signs of experimental autoimmune encephalomyelitis. J ournal of Neuroimmunology, 28: 177-184.

40. Levy G, Tarrab-Hazdai R \& Teichberg VI (1983). Prevention and therapy with electrolectin of experimental autoimmune myasthenia gravis in rabbits. European J ournal of Immunology, 13: 500-507.

41. Perillo NL, Pace KE, Seilhamer JJ \& Baum LG (1995). Apoptosis of T-cells mediated by galectin-1. Nature, 378: 736-739.

42. Yamaoka A, Kuwabara I, Frigeri LG \& Liu FT (1995). A human lectin, galectin-3 (epsilon BP/Mac-2), stimulates superoxide production by neutrophils. J ournal of Immunology, 154: 3479-3487.

43. Iglesias MM, Rabinovich GA, Ivanovic $V$, Sotomayor CE \& Wolfenstein-Todel C (1998). Galectin-1 from ovine placenta: amino-acid sequence, physicochemical properties and implications in T-cell death. European J ournal of Biochemistry, 252: 400-407.

44. Iglesias MM, Rabinovich GA, Ambrosio $A L$, Castagna LF, Sotomayor CE \& Wolfenstein-Todel CW (1998). Purification of galectin-3 from ovine placenta: developmentally regulated expression and immunological relevance. Glycobiology, 8: 59-65.

45. Raz A \& Lotan R (1987). Endogenous galactoside-binding lectins: a new class of functional tumor cell surface molecules related to metastasis. Cancer and Metastasis Reviews, 6: 433-452.

46. Zhou Q \& Cummings RD (1993). L-14 lectin recognition of laminin and its promo- tion of in vitro cell adhesion. Archives of Biochemistry and Biophysics, 300: 6-17.

47. Ozeki $Y$, Matsui T, Yamamoto $Y$, Funahashi M, Hamako J \& Titani K (1995). Tissue fibronectin is an endogenous ligand for galectin-1. Glycobiology, 5: 255261.

48. Van den Brüle FA, Buicu C, Baldet $M$ Sobel ME, Cooper DNW, Marschal P \& Castronovo V (1995). Galectin-1 modulates human melanoma cell adhesion to laminin. Biochemical and Biophysical Research Communications, 209: 760-767.

49. Mahanthappa NK, Cooper DNW, Barondes SH \& Schwarting GA (1994). Rat olfactory neurons can utilize the endogenous lectin L-14, in a novel adhesion mechanism. Development, 120: 13731384.

50. Cooper DNW, Massa SM \& Barondes SH (1991). Endogenous muscle lectin inhibits myoblast adhesion to laminin. J ournal of Cell Biology, 115: 1437-1448.

51. Kuwabara I \& Liu F-T (1996). Galectin-3 promotes adhesion of human neutrophils to laminin. J ournal of Immunology, 156: 3939-3944.

52. Ochieng J , Leite-Browning ML \& Warfield P (1998). Regulation of cellular adhesion to extracellular matrix proteins by galectin-3. Biochemical and Biophysical Research Communications, 246: 788-791.

53. Bresalier RS, Mazurek N, Stemberg LR, Byrd J C, Yunker CK, Makker PN \& Raz A (1998). Metastasis of human colon cancer is altered by modifying expression of the B-galactoside binding protein galectin-3. Gastroenterology, 115: 287-296.

54. Sanford GL \& Harris-Hooker S (1990). Stimulation of vascular cell proliferation by ß-galactoside-binding lectins. FASEB J ournal, 4: 2912-2918.

55. Adams L, Kenneth Scott $G \&$ Weinberg $C$ (1996). Biphasic modulation of cell growth by recombinant human galectin-1. Biochimica et Biophysica Acta, 1312: 137144.

56. Roberts $A B$, Anzano MA, Wakefield $L M$, Roche NS, Stern DF \& Sporn MB (1985). Type beta transforming growth factor: a bifunctional regulator of cell growth. Proceedings of the National Academy of Sciences, USA, 82: 119-123.

57. Lynch DH, Ramsdell $F$ \& Alderson MR (1995). Fas and Fas $L$ in the homeostatic regulation of immune responses. Immunology Today, 16: 569-574.

58. Karlsson A, Follin $\mathrm{P}$, Leffler $\mathrm{H} \&$ Dahigren C (1998). Galectin-3 activates the NADPH oxidase in exudated but not peripheral blood neutrophils. Blood, 91: 3430-3438. 
59. Matsumoto $R$, Matsumoto $H$, Seki $M$, Hata M, Asano Y, Kanegasaki S, Stevens RL \& Hirashima M (1998). Human ecalectin, a variant of human galectin-9, is a novel eosinophil chemoattractant produced by T lymphocytes. J ournal of Biological Chemistry, 273: 16976-16984.

60. Ogden AT, Nunes I, Ko K, Wu S, Hines CS, Wang AF, Hegde RS \& Lang RA (1998). GRIFIN, a novel lens-specific protein related to the galectin family. J ournal of Biological Chemistry, 273: 2888928896.

61. Griffith TS \& Ferguson TA (1997). The role of Fas L-induced apoptosis in immune privilege. Immunology Today, 18: 240244.

62. Gold R, Hartung HP \& Lassman H (1997). T-cell apoptosis in autoimmune diseases: termination of inflammation in the nervous system and other sites with specialized immune-defense mechanism. Trends in Neurosciences, 20: 399-404.

63. Baum LG, Seilhamer J J, Pang M, Levine WB, Beynon D \& Berliner J A (1995). Synthesis of an endogenous lectin, galectin-1 by human endothelial cells is up-regulated by endothelial cell activation. Glycoconjugate J oumal, 12: 63-68.

64. Baum LG, Pang $M$, Perillo $N L, W u T$, Delegaene $\mathrm{A}$, Uittenbogaart $\mathrm{CH}$, Fukuda M \& Seilhamer J J (1995). Human thymic epithelial cells express an endogenous lectin, galectin-1, which binds to core 20 glycans on thymocytes and T lymphoblastoid cells. J ournal of Experimental Medicine, 181: 877-887.

65. Blaser $C$, Kaufmann M, Muller $C$, Zimmerman C, Wells V, Mallucci L \& Pircher H (1998). B-galactoside-binding protein secreted by activated $T$ cells inhibits antigen-induced proliferation of $\mathrm{T}$ cells. European J ournal of Immunology,
28: 2311-2319.

66. Allione A, Wells V, Forni G, Mallucci $L \&$ Novelli $F$ (1998). B-galactoside-binding protein (B-GBP) alters the cell cycle, upregulates expression of the $\alpha$ - and $\beta$ chains of the IFN- $\gamma$ receptor, and triggers IFN- $\gamma$-mediated apoptosis of activated human T lymphocytes. J ournal of Immunology, 161: 2114-2119.

67. Cortegano I, del Pozo V, Cárdaba B, de Andres B, Gallardo S, del Amo A, Arrieta I, J urado A, Palomino P, Liu F-T \& Lahoz C (1998). Galectin-3 down-regulates IL-5 gene expression on different cell types. J ournal of Immunology, 161: 385-389.

68. Goldstone SD \& Lavin MF (1991). Isolation of a cDNA clone, encoding a human ß-galactoside-binding protein overexpressed during glucocorticoid-induced cell death. Biochemical and Biophysical Research Communications, 178: 746-750.

69. von Boehmer H (1994). Positive selection of lymphocytes. Cell, 76: 219-228.

70. Nossal GJ V (1994). Negative selection of lymphocytes. Cell, 76: 229-239.

71. Perillo NL, Uittenbogaart $\mathrm{CH}$, Nguyen J T \& Baum LG (1997). Galectin-1, an endogenous lectin produced by thymic epithelial cells, induces apoptosis of human thymocytes. J ournal of Experimental Medicine, 97: 1851-1858.

72. McFarland HL, Critchfield J M, Racke MK, Mueller JP, Nye SH, Boehme SA \& Lenardo MJ (1995). Amelioration of autoimmune reactions by antigen-induced apoptosis of T cells. Advances in Experimental and Medical Biology, 383: 157166.

73. Cyster J G, Fowell D \& Barclay AN (1994). Antigen determinants encoded by alternatively spliced exons of CD45 are determined by the polypeptide but influenced by glycosylation. International Immunol- ogy, 6: 1875-1881.

74. Singer GG, Carrera AC, MarshakRothstein A, Martínez AC \& Abbas AK (1994). Apoptosis, Fas and systemic autoimmunity: the MRL-Ipr/lpr model. Current Opinion in Immunology, 6: 913-920.

75. Fisher GH, Rosenberg FJ , Straus SE, Dale J K, Middelton LA, Yin AY, Strober W, Lenardo MJ \& Puck J M (1995). Dominant interfering Fas gene mutations impair apoptosis in a human autoimmune lymphoproliferative syndrome. Cell, 81: 935-946.

76. Yang RY, Hsu DK \& Liu FT (1996). Expression of galectin-3 modulates T cell growth and apoptosis. Proceedings of the National Academy of Sciences, USA, 93: 6737-6742

77. Kroemer G (1997). The proto-oncogene $\mathrm{BCl}-2$ and its role in regulating apoptosis. Nature Medicine, 3: 614-620.

78. Wada J , Ota K, Kumar A, Wallner EI \& Kanwar Y (1997). Developmental regulation, expression and apoptotic potential of galectin-9, a ß-galactoside-binding lectin. J ournal of Clinical Investigation, 99: 2452-2461.

79. Rabinovich GA, Modesti NM, Castagna LF, Landa CA, Riera CM \& Sotomayor CE (1997). Specific inhibition of lymphocyte proliferation and induction of apoptosis by CLL-I, a ß-galactoside-binding lectin. J ournal of Biochemistry, 122: 365-373.

80. Revillard J P, Adorini L, Goldman $M$, Kabelitz D \& Waldmann H (1998). Apoptosis: potential for disease therapies. Immunology Today, 19: 291-293.

81. Lutomski D, J oubert-Caron R, Lefebure C, Salama J Belin C, Bladier D\& Caron M (1997). Anti-galectin-1 autoantibodies in serum of patients with neurological diseases. Clinica Chimica Acta, 262: 131-138. 